\title{
Thoughts of a Medical Doctor about the Life Periods of Our Earth and the Evolution
}

\author{
Béla Ralovich \\ Ministry of Welfare (retired), Budapest, Hungary \\ Email: ralovich.b@gmail.com
}

How to cite this paper: Ralovich, B. (2018) Thoughts of a Medical Doctor about the Life Periods of Our Earth and the Evolution. Open Journal of Applied Sciences, 8, 411-421.

https://doi.org/10.4236/ojapps.2018.89031

Received: August 23, 2018

Accepted: September 26, 2018

Published: September 29, 2018

Copyright $\odot 2018$ by author and Scientific Research Publishing Inc. This work is licensed under the Creative Commons Attribution International License (CC BY 4.0).

http://creativecommons.org/licenses/by/4.0/

(c) (i) Open Access

\begin{abstract}
The author thinks that the endless and timeless Universe is a permanent substance and energy flow as well as motion of celestial systems and bodies. Celestial bodies may have physical and biological life. Our Earth has both lives which can be divided into different periods of time. Its physical life can mainly be characterized by the atomic evolution, sterility, appearance of water and abiotic chemical reactions. Essence of the biological life is the existence of the living unit. Biological life of our Globe started with the first living unit/microorganism which began to influence on its environment which is a closed system for substance, flora, creature and man but not for hit of celestial bodies and for arrival of different kinds of energy from the space as well as for radiation of heat. The biological life of our Earth can be divided into four parts: before photosynthesis, before mankind, before 1778 and after the industrial revolution.
\end{abstract}

\section{Keywords}

Energy and Substance Flow, Physical Life, Atomic Evolution, Sterility, Closed System, Biological Life and Its Effects on the Environment, Biological Evolution

\section{Preface}

The Universe is endless substance and energy flow with motion of celestial systems and bodies (including galaxies, Sun-systems, stars, comets, meteors, etc.) on the basis of the low of Nature/God. Men are not able to know and imagine the total Universe. When the relation between substance, energy and time is studied then it can be concluded that continuous change of the substance and energy represents/means the passing time. Celestial systems and bodies of the Universe are different depending on their type, position and age. It is supposed 
that our Galaxy was born more than 10 billion years ago and the age of our solar-system and that of our Earth existing in that system may be $5-4.75$ and 4.55 billion years, respectively. The birth of our Galaxy was the consequence of unknown movement of the substance and energy. In our solar system celestial bodies get energy mainly from our Sun and they have radiated heat [1] [2] [3].

As to the life of our Planet it has lasted from its birth through the present up till its demolition which process can be divided into at least two basic periods: "true" physical life in brief: physical life and physical life together with biological life in brief: biological life.

\section{Physical Life of Our Earth (0 - 3.75/3.8 Billion Ys.)}

True physical life of celestial bodies is not unchanged. They may have some common characteristics: birth, motion, atomic evolution, cooling, geological events, regular fluctuation of their temperature (effect of Sun), sterile condition, appearance of water and abiotic chemical reactions.

As to the physical life of our Earth it can be supposed that it started as a glowing star consisted of hydrogen $\left(\mathrm{H}_{2}\right)$, helium $(\mathrm{He})$ as well as atomic fusion. Its early atmosphere might be a solar type with the same components. That starting process can be named atomic evolution during of which different atoms-nitrogen $\left(\mathrm{N}_{2}\right)$, carbon $(\mathrm{C})$, phosphor $(\mathrm{P})$, sulfur $(\mathrm{S})$ and the others (stable elements and naturally radioactive ones) as well as simple molecules had been formed. It is probable that the atomic/substantial pool of our Earth evolved by the end of solidification of its surface. This pool is practically constant (except the naturally radioactive elements) - as only celestial bodies may bring some substance from the space on our Earth and nothing can leave it on natural way-therefore it is a closed system for substances but not for the different kinds of energy.

The connections among the atoms are not permanent. They may change time to time depending on the actual energetic condition and on the actual possibility of a chemical reaction. The possibility of that change is the base not only for the atomic evolution and the abiotic chemical reactions but also for the biological life and biological evolution, too.

\subsection{Solidification of the Surface of Our Earth}

It is probable that the atomic evolution practically ended by the solidification of the surface of our Globe. The substance and structure of the first abiotic solid surface of our Planet are not known but it may be supposed that the composition of its early laves and that of the surface samples of other lifeless celestial bodies may be similar to that surface. We do not know what does happen in the depth of our Earth at present.

\subsection{Changes of the Atmosphere}

The first solar type atmosphere of our Globe had also changed. It is supposed that it transformed into a reductive/anaerobic (?) one containing $\mathrm{N}_{2}$ and/or 
carbon monoxide $(\mathrm{CO})$ or carbon dioxide $\left(\mathrm{CO}_{2}\right)$ etc. The reduction is a process in which a substance gains electron and its positive valence decreases. Point of time of appearence of oxygen $\left(\mathrm{O}_{2}\right)$ and that of the processe of oxydation which means that an atom loses electron with an accompanying increase in its positive valence is an open question. $\mathrm{CO}, \mathrm{CO}_{2}$ and water $\left(\mathrm{H}_{2} \mathrm{O}\right)$ could not be formed without $\mathrm{O}_{2}$. Physical burning needs also $\mathrm{O}_{2}$. It is a big question-mark when and how did $\mathrm{CO}, \mathrm{CO}_{2}$ and $\mathrm{H}_{2} \mathrm{O}$ appear and what was their birth order? It is sure that the formation of $\mathrm{CO}, \mathrm{CO}_{2}$ and water had happened many 100 million years ago.

\subsection{Importance of Carbon Compounds and Fluid Water}

Without carbon compounds and fluid water there is not life. It is sure that fluid water or ice came into view only when the Earth's surface was already rigid and its temperature as well as the atmospheric pressure gave the possibility of its condensation and/or freeze. It can be supposed that $\mathrm{CO}, \mathrm{CO}_{2}$ and perhaps water vapour had also existed before the presence of fluid water or ice. Appearance of fluid water was a very important event not only from both chemical and later biological processes because water is a medium for chemical reactions that is for formation of abiotic inorganic and organic compounds as well as later for formation of the first living unit but for the so called water circulation, too. We do not know when, how and why did circulation start which process together with the atmospheric $\mathrm{CO}_{2}$ have played important role in regulation of the actual temperature of our Globe.

\subsection{Parts of the True Physical Life of Our Earth}

On the basis of the facts we think that the true physical life of our Earth-which was sterile/abiotic-had three parts.

The first one can be characterized by atomic, physical and geomorphological events.

The second part started when the surface of our Earth became massive.

The third one began with the appearance of water and this part lasted till the birth of the first living unit.

\section{Biological Life of Our Planet (from the Age of 3.75/ 3.8 Billion Years - ?)}

After the birth of our Earth in consequence of the mentioned sterile physical, geological and chemical processes which supposedly lasted for 3.75/3.8 billion years-the first living substantial matrix that is the biological life appeared. The biological life is a special energetic and substantial phenomenon of a matrix which formed on the basis of the true physical life of our Globe. Its formation is not known but it is a fact that it could form and exist only in fluid water containing the necessary dissolved inorganic as well as organic substances which were already built up in abiosis. Besides these the temperature and $\mathrm{pH}$ of the water as well as the atmospheric conditions had to be optimal and a convenient energetic donor in the environment as well as a suitable acceptor for the energy in the matrix had to be 
also present. It would be interesting to list of the kinds of the inorganic and organic compounds which were necessary for the simpliest living matrix. It seems that the abiotic environmental chemistry knew already everything. We do not know what is the situation with the biological life in the other parts of the endless Universe.

\subsection{The Living Unit and Its Life}

The first living unit is a substantial matrix which is bordered by a permeable membrane/wall. During the life of this unit-inside its cell and through its membrane/wall - a characteristic organized and directed energy and substance transport that is metabolism flows which requires energy. The living unit is affected by external effects and it can accommodate to those only within the borders of its own life requirements. In the same time it influences on its environment, too. The living unit can change and its genetic material can mutate. Also this unit can multiply and its characteristics are bequeathed into its posterities.

The start of the life of the first living unit is unknown although energetic conditions of the biological life were studied by E. Schrödinger and A. Katsuki, too [4]. They stated that the life needed environment of low entropy because consumption of compounds of low entropy (e.g., saccharides and so on) which were essential for it was only possible in such circumstance. Suitable condition of entropy of our Earth has been ensured by the circulation of water and by the composition and condition of its atmosphere as well as its surface.

\subsection{About the First Living Unit}

The first living unit appeared about 800 - 750 million years ago on our Earth, if the present observations and calculations are exact. As for its characteristics it might be a pluripotent archaic type cell without membrane bound nucleus and other distinct organelles that is it was a procarya/prokaryote. It is thought that its metabolism-in accordance with the anaerobic (semianaerobic?) condition which is supposed-might be chemotrophiclautotrophic (perhaps heterotrophic?) but what was its substantial and energetic background it is unknown for us. We only know that the birth and existence of the procarya required an outer energy donor as well as an own operating structure which could accept the energy and maintain its own metabolism. Besides this it is also fact that some of the compounds produced by the unit contained chemically bound energy (accumulator function) and during its metabolism heat was also liberated. Furthermore we know that at present such microorganisms have also lived which can survive a temperature more than $100^{\circ} \mathrm{C}$ or a temperature lower one than $0^{\circ} \mathrm{C}$, an atmospheric pressure more than 1 bar and the high saline concentration, too. Without procarya there would not be any biological life on our Earth.

\subsection{Effect of the Procarya}

Since the appearance of the first procarya sterile condition of our Earth disappeared. That microorganism had permanently as well as in a growing 
degree-in consequence of its multiplication-started to decompose, consume and transform inorganic as well as the already existing organic substances of abiosis and had produced different types of inorganic as well as organic compounds, gas and heat. Its cells became the first organic mud of waters as well as the first complex organic components of ground and they formed the first ecosystem/microbiome, too. Without their activity the surface of our Globe would be similar to that of the other lifeless celestial bodies (see Figure 1).

\subsection{Birth of Different Cells}

Genetic changes/mutations first happened during the life of some of the Archaea cells in consequence of which and of the environmental selection different types of microbial cells-bacterial, eucaryal (fungal, plant and animal)-have appeared that is the biological evolution has begun. One variety of the phylogenetic trees can be seen in Figure 2 [5].

\subsection{Effect of Phototrophic Organisms}

As a result of genetic changes of archaic microorganisms the first phototrophic cell appeared and started to consume not only $\mathrm{CO}_{2}$ and other substances needed for its life but solar energy also as well as to emit free $\mathrm{O}_{2}$. During the next more ten million years the concentration of the free $\mathrm{O}_{2}$ increased in the earthly environment. As during the photosynthesis $\mathrm{CO}_{2}$ and solar energy are used for production of organic compounds this process results in a shorter or longer fixation of substance and energy-accumulator function. The carbon and the energy remain bound in the phototrophic cells till their decomposition by a living organism or till their physical combustion. The phototrophic organisms because of their great mass and photosynthetic activity as well as that they produce free $\mathrm{O}_{2}$ have played determinative role in the energetic and substantial processes of
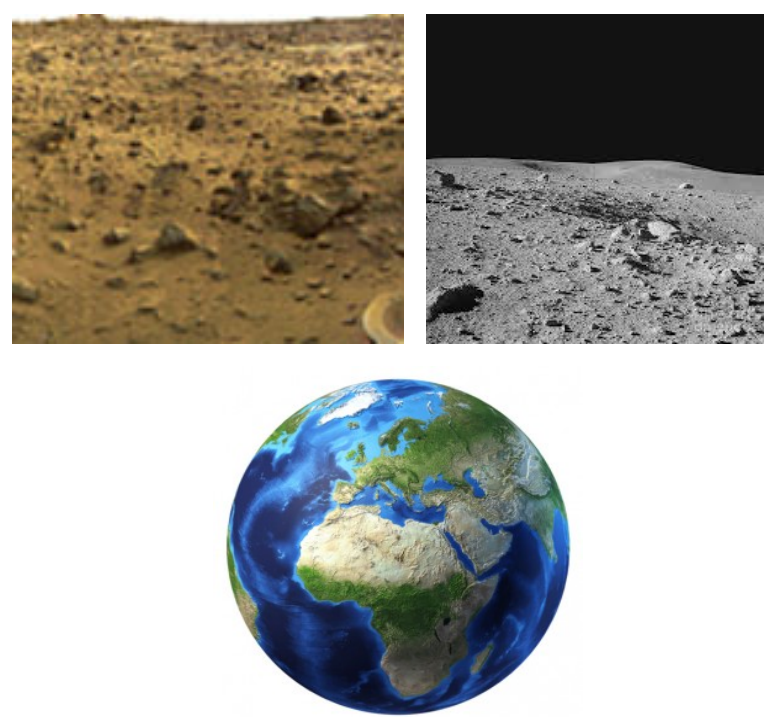

Figure 1. The surface of the Mars as well as that the Moon and the picture of the Earth. 


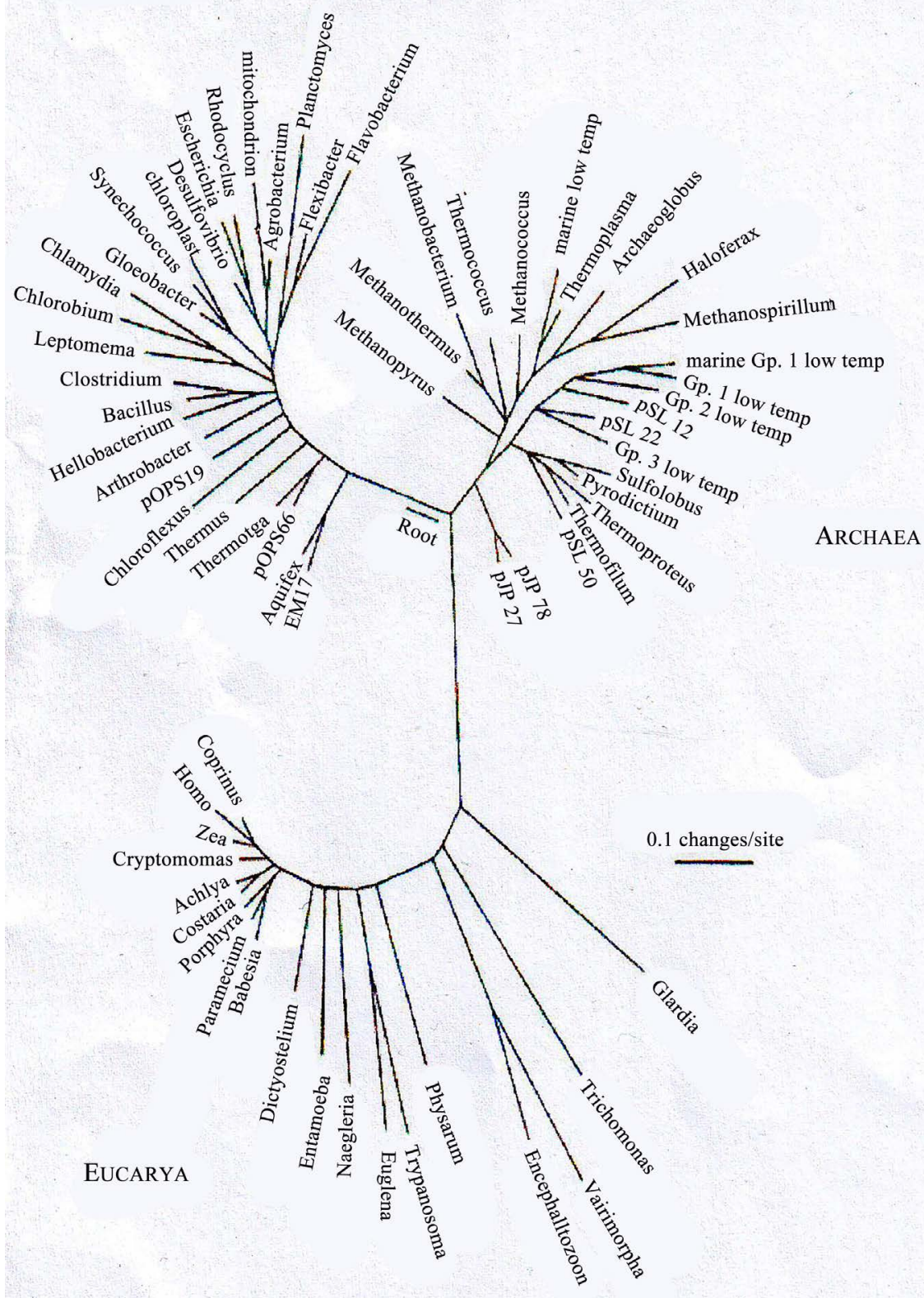

Figure 2. Phylogenetic tree of procarya, bacteria and eucarya cells by M. Dworkin et al. [5].

our Earth mainly that in the past a lot of them got into the depth of our Globe where they transformed into oil, coals as well as gas during millions of years. In consequence of these events the energy and carbon bound by the phototrophic cells had omitted from the usual circulation of energy and substance which could result in decreasing of the concentration of free $\mathrm{CO}_{2}$ and also that of temperature which process went with biological consequences. The recent forced use of the energetic raw materials liberates very fast-only during some 250 years-almost all the bound energy and carbon which process has influenced on the present earthly environment and climate.

Increasing concentration of the free $\mathrm{O}_{2}$ in the earthly environment helped not 
only fulfilling of aerobic respiration but also the formation of the animal world the members of which-except carnivorous ones-consumed plants, $\mathrm{O}_{2}$, water and so on to get the necessary substances and energy for their life. After about a 720 - 770 million years long biological evolution the first two men appeared less than 30 million years ago and the anthropoid period of our Globe has started. The appearence of men-as you will see later-has very serious consequences.

\section{Results}

The anthropoid period can be characterized by the effects of man kind of growing number and by the consequences of their consciouse activities-mainly by the use of fire and by the preparation of different artificial chemical compounds-together with all former influencing factors which continuously exist. That part had an important turning point in 1778. Since that date the industrial revolution has flowed with all its consequences. The man kind has determinative effects on the physical and biological condition of our Earth. A small part of those changes which were caused by man kind can be seen in Figure 3 and in the Tables. Figure 3 shows measured values of eleven parameters which are: number of man kind, that of oxen, quantity of energies (water, atomic, wind) used, that of energetic raw materials (coal, gas, oil) burned, territory of forests, average temperature of the Earth and finally $\mathrm{CO}_{2}$ concentration in the earthly atmosphere. Each value of all parameters-except that of the territory of forests-has continuously increased [6] [7] [8] [9]. As to our calculations some of them are presented in Table 1(a) and Table 1(b). Each calculated value has became bigger during the period of observation. These facts mean that the artificial loading of the environment has grown since the appearance of men.

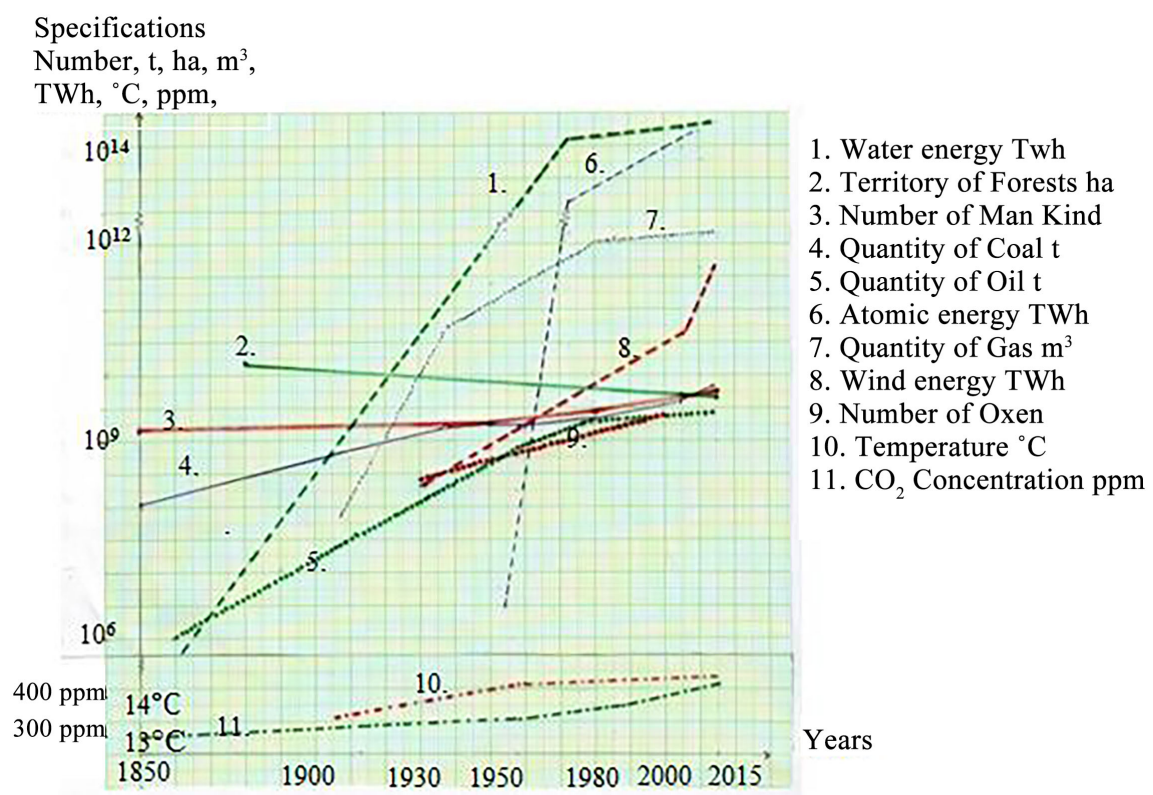

Figure 3. Number of man kind and oxen; Quantity of energetic raw materials and energies; Dimension of territory of forests; Average temperature of the Earth and $\mathrm{CO}_{2}$ content of the atmosphere between the years of 1850-2015. 
Table 1. Data to the circulation of energy and $\mathrm{CO}_{2}$ on the Earth.

(a)

\begin{tabular}{|c|c|c|c|c|c|c|}
\hline \multirow{2}{*}{ Specifications } & \multicolumn{6}{|c|}{$\begin{array}{l}\text { Mass of fuels as well as their average thermal values and the quantity of } \mathrm{CO}_{2} \text { liberated from them; } \\
\text { other energies number and emissions of man kind and oxen at different point of time. }\end{array}$} \\
\hline & 1860 & $1935+37$ & 1958 & 1980 & $2000+05$ & $2009+14$ \\
\hline oil $\times 10^{6} t$ & 1 & 279.5 & 809.8 & 3059 & 3590 & 4117 \\
\hline $40.5 \mathrm{MJ} / \mathrm{ka}$ & $4.05 \times 10^{10}$ & $1.13 \times 10^{13}$ & $3.27 \times 10^{13}$ & $1.23 \times 10^{14}$ & $1.45 \times 10^{14}$ & $1.66 \times 10^{14}$ \\
\hline $\mathrm{CO}_{2} \mathrm{~m}^{3}$ & $3.17 \times 10^{9}$ & $8.86 \times 10^{11}$ & $2.56 \times 10^{12}$ & $9.69 \times 10^{12}$ & $1.13 \times 10^{13}$ & $1.3 \times 10^{13}$ \\
\hline $\operatorname{coal} \times 10^{6} \mathrm{t}$ & 136 & 1280 & 1762 & 2805 & 5878 & 7823 \\
\hline $20.35 \mathrm{MJ} / \mathrm{kg}$ & $2.76 \times 10^{12}$ & $2.6 \times 10^{13}$ & $3.58 \times 10^{13}$ & $5.7 \times 10^{13}$ & $1.18 \times 10^{14}$ & $1.59 \times 10^{14}$ \\
\hline $\mathrm{CO}_{2} \mathrm{~m}^{3}$ & $3.12 \times 10^{11}$ & $2.92 \times 10^{12}$ & $4.05 \times 10^{12}$ & $6.45 \times 10^{12}$ & $1.37 \times 10^{13}$ & $1.72 \times 10^{13}$ \\
\hline Gas $\times 10^{9} \mathrm{~m}^{3}$ & un. & 71 & 400 & 1531 & 2778 & 3479 \\
\hline $37 \mathrm{MJ} / \mathrm{kg}$ & un. & $2.62 \times 10^{12}$ & $1.48 \times 10^{13}$ & $5.66 \times 10^{13}$ & $1.02 \times 10^{14}$ & $1.28 \times 10^{14}$ \\
\hline $\mathrm{CO}_{2} \mathrm{~m}^{3}$ & un. & $1.37 \times 10^{11}$ & $7.72 \times 10^{11}$ & $2.95 \times 10^{12}$ & $5.36 \times 10^{12}$ & $6.72 \times 10^{12}$ \\
\hline \multicolumn{7}{|l|}{ All together } \\
\hline $\mathrm{MJ} / \mathrm{kg}$ & $2.8 \times 10^{12}$ & $3.99 \times 10^{13}$ & $8.33 \times 10^{13}$ & $1.8 \times 10^{14}$ & $3.66 \times 10^{14}$ & $4.53 \times 10^{14}$ \\
\hline $\mathrm{CO}_{2} \mathrm{~m}^{3}$ & $3.15 \times 10^{11}$ & $3.94 \times 10^{12}$ & $7.38 \times 10^{12}$ & $1.9 \times 10^{13}$ & $3.01 \times 10^{13}$ & $3.69 \times 10^{13}$ \\
\hline
\end{tabular}

Abbreviation: un. = datum is unknown .

(b)

\begin{tabular}{|c|c|c|c|c|c|}
\hline Specifications & 1866 & 1931 & 1954 & 1973 & $2005-2010$ \\
\hline \multicolumn{6}{|l|}{ Different energies } \\
\hline Water TWh & 0 & un. & un. & 1296 & 3000 \\
\hline Wind GW & & $0.3^{* * * * * *}$ & un. & un. & 59 \\
\hline Atomic TWh & & & $5^{* * * * * *}$ & 203 & 2461 \\
\hline No. and emissions of men & 1850 & 1937 & 1950 & 1980 & un. \\
\hline Milliard & 1.17 & 2.1 & 2.5 & 4.4 & un. \\
\hline $\mathrm{CO}_{2} \mathrm{~m}^{3} /$ year & $3.2 \times 10^{8 *}$ & $5.75 \times 10^{8}$ & $6.85 \times 10^{8}$ & $1.2 \times 10^{9}$ & un. \\
\hline $\begin{array}{c}\text { When } 25 \% \text { of the metabolism } \\
\text { is heat W/year }\end{array}$ & $9.39 \times 10^{12 * *}$ & $1.68 \times 10^{13}$ & $2.0 \times 10^{13}$ & $3.53 \times 10^{13}$ & un. \\
\hline No. and emissions of oxen & & 1930-ties & & & $1999-2000$ \\
\hline Million & & 438.9 & & & 1351.4 \\
\hline $\mathrm{CO}_{2} \mathrm{~m}^{3} /$ year & & $4.98 \times 10^{10 \star * *}$ & & & $1.53 \times 10^{11 \star * *}$ \\
\hline $\begin{array}{c}\text { When } 50 \% \text { of the } \\
\text { metabolism is heat W/year }\end{array}$ & & $3.29 \times 10^{13 * * * *}$ & & & $1.01 \times 10^{14 * * * *}$ \\
\hline Methane litre/year & & $4.38 \times 10^{10}-8.0 \times 10^{13 * * * * *}$ & & & $4.93 \times 10^{11}-2.46 \times 10^{14 * * * * *}$ \\
\hline
\end{tabular}

Abbreviations: un. $=$ datum is unknown, ${ }^{*}=$ in case of basic metabolism of a person: $2701 /$ day, ${ }^{* *}=$ in case of basic metabolism of a person: $88 \mathrm{~W} /$ day, ${ }^{* *}=$ on the basis of an experimental datum of one calf of $75 \mathrm{~kg}: 311 \mathrm{l} / \mathrm{day},{ }^{* * *}=$ on the basis of an experimental datum of one calf of $75 \mathrm{~kg}: 89.16 \mathrm{~W} / \mathrm{day}$, ${ }^{* * * *}=$ data of oxen: $100-500 \mathrm{l} /$ day/animal, ${ }^{* * * * *}=\mathrm{MW}$. 


\section{Conclusions}

\subsection{The Periods of the Biological Life of Our Earth}

On the basis of the facts we think that the biological life of our Earth can be divided into four periods. It is necessary to know about these periods because each of them had/have special energetic and substantial processes which had/have biological consequences and vice versa.

The first period lasted from the appearance of the first living unit till the beginning of photosynthesis. That part might be an anaerobic (semianaerobic?) section in which biological transformation of earthly environment and the natural mutation of microorganisms have started.

The second one lasted from the start of photosynthesis till the appearance of the first two men. During that period of time biological fixation of solar energy as well as free $\mathrm{CO}_{2}$ and production of free $\mathrm{O}_{2}$ by phototrophs have started and the biological evolution has continued. This two periods can be described by only natural biological processes and by their consequences besides those lifeless effects which have permanently determined the earlier true physical life of our Planet, too. No unnatural event had happened during these two periods.

The third period ended in 1778 and the last one has existed since that point of time.

\subsection{The Life in a Closed System}

The so called closed system is a special environment which has different types. Those parts of the Earth and the earthly surrounding all together which are suitable for a living unit at least to survive is called Biosphere. Our Biosphere is a special closed system because only celestial bodies may bring some substance from the space into it and no substance, flora, creature as well as man can leave it on natural way. In the same time it is open for arrival different kinds of energy and it can radiate and reflec heat. In case of an artificial closed system-e.g., a cultivation tank is one of such systems-it is obligatory permanently to ensure those conditions (water, food, temperature, $\mathrm{pH}$, atmosphere, circulation, elimination of metabolites and over population) which are necessary for the continuous life and reproduction of the given living organism mass cultivated. Our Earth is a closed system for the biological life.

\subsection{Consequences of the Existence of Man Kind}

On the basis of the collected data and of our own calculations mentioned above — which were published earlier [6] [7] [8] [9] —it can be concluded that during the anthropoid period-especially from 1778 and later after 1940-such energetic and substantial changes have happened on our closed Earth and in its atmosphere which are very different from the substantial and energetic situation of the earlier periods which are: before the appearance of the first living unit or that of the photosynthetic cell or that of the first two men or when the industrial revolution started. Causes and consequences of these changes can roughly be 
summarized in three points.

The first point contains the number, requirements and activities of human beings and farm animals in a closed system. For example: environmental effects of fire and of the other kinds of energy; that of industry-mainly by all artificial substances; that of agriculture-especially by animal breeding of industrial and by intensive mass-production of plants; that of transport and military activities; that of communal processes; that of scientific events-mainly by the atomic, space and the recent gene modifying experiments; that of the philosophy of profit and that of the endless wishes of men.

Into the second point alterations of the surface of our Earth can be listed. Its natural surface has been modified by buildings, roads, deforestation, mines, farming lands, reservoirs and contamination of surface waters. These changes have modified the original possibilities of absorption, adsorption, reflection and utilization of solar energy, the heat radiation of the Earth as well as the movement of waters. Besides these they have great many unpleasant ecological consequences, too.

$\mathrm{CO}_{2}$ and non-inert gases, vapours, dusts and movement of aircraft and rockets belong to the third point. They have influenced on the composition and condition of the atmosphere of our Earth in consequence of which original way of arrival of solar energy as well as that of leaving of heat and the natural mode of water circulation have been modified.

In consequence of the alterations listed above the climate of our Earth has also continuously changed that is worsend.

\section{What Can Be Expected from Future?}

When somebody thinks about the essence and the aim of the biological life then it can be concluded that it is only a new life in a natural closed environment on the basis of the low of Nature/God and not on the basis of the imaginations of men. This rule ought to have determined the life of man kind all time but it has always failed. Therefore the unpleasant alterations in our closed Biosphere have permanently grown and in consequence of that the condition as well as perspective of the human life have continuously worsend. Perhaps there is still time enough to save the human life but for that it is necessary to order drastic restrictions immediately.

\section{Note}

Earlier parts of this paper were presented on the Veterinary University of Budapest (an ATE BK CT Meeting) at 2nd March, 2017; on the "1st International Conference on Community Ecology" Budapest at 28-29 September, 2017; on the "International Congress on Microbial \& Biochemical Research and Technologies" and "Global Applied Microbiology Conference" (video presentation) Toronto at 18-19 October, 2017 and on " 5 th Central European Forum for Microbiology" Keszthely at 18-20 October, 2017. 
This full paper was/is accepted for presentation on different Conferences of 2018. These are: "International Conference on Earth Science and Climate Change" (video presentation) was held on 6-7 September, in Zurich, Switerland; "The International Conference on Plant and Soil Sciences" (video presentation) was held on 17-19 September, in Osaka, Japan and finally the "International Summit on Microbiology and Parasitology 2018" to be held on 25-26 October, at Prague, Czech Republic.

The Hungarian version of this paper entitled "Gondolatok a Föld fizikai és biológiai életérõl” was published in May in Búvópatak XVII, 27-29 (2018). www.buvopatak.hu (search for).

\section{Conflicts of Interest}

The author declares no conflicts of interest regarding the publication of this paper.

\section{References}

[1] Simonyi, K. (1998) A fizika kultúrtörténete a kezdetektől 1990-Ig. Akadémiai Kiadó, Budapest.

[2] Ralovich, B. (2004) Az öreg ember és a gondolatok. Püski Kiadó Kft., Budapest.

[3] Ralovich, B. (2011, 2014, 2018) Adatok a mikrobiológiával kapcsolatos ismeretek Oktatás-És kutatástörténetéhez. I.-III. kötet, TSR Kft., Keszthely.

[4] Katsuki, A. (1988) A Föld, az élőlények és az entrópia. Fizikai Szemle, XXXVIII, 102-110.

[5] Dworkin, M., Falkow, S., Rosenberg, E., Schleifer, K.-H. and Stackebrandt, E. (2006) The Prokaryotes. Springer Science + Business Media, LLC, New York.

[6] Ralovich, B. (2014) The Place of Our Earth in the Universe and Turning-Points in its Life (Thoughts Induced by the Climate Change). American Association for Science and Technology, 1, 116-119.

http://www.aascit.org/communications/paperInfo?journalId=940\&paperId=787

[7] Ralovich, B. (2016) Data on the Changes Occurring in the Biosphere since 1778. Open Journal of Ecology, 6, 387-403. https://doi.org/10.4236/oje.2016.67037

[8] Ralovich, B. (2017) The Effect of the Biological Life and Man Kind on the Earth (Mainly between 1778 and 2015). Journal of Ecology and Toxicology, 1, 1-4.

[9] Ralovich, B. (2017) The Place of Our Earth in the Universe and Turning-Points in its Life. In: Narro, A., Folloni, A., Pitasi, A. and Ruzzeddu, M., Eds., Inventing the Future in an Age of Contingency, Cambridge Scholars Publishing, Newcastle upon Tyne, UK, 203-209. 